\title{
Effect of Brachiaria Grass on Vegetative Development of Teak ${ }^{1}$
}

\author{
Fausto Antônio Domingos Júnior ${ }^{1}$, Lisias Coelho² \\ ${ }^{1}$ Instituto Federal do Triângulo Mineiro - IFTM, Uberaba, MG, Brasil \\ ${ }^{2}$ Instituto de Ciências Agrárias - ICIAG, Universidade Federal de Uberlândia - UFU, Uberlândia, MG, Brasil
}

\begin{abstract}
Invasive plants are a limiting factor for the establishment of planted teak (Tectona grandis L.f.) forests, especially because most of them are planted on Urochloa decumbens Stapf degraded pastures. This study evaluated initial teak development applying different control alternatives for $U$. decumbens. Treatments were no weed control (T1), continuous control of $U$. decumbens (T2), $U$. decumbens control after six months of competition (T3), and $60 \mathrm{~cm}$ control of $U$. decumbens around the seedlings (T4). The experiment was established in a pasture, containing $U$. decumbens, in May 2012. The experimental design was randomized blocks, with four treatments and four replications. Twenty two months after transplanting the seedlings, all treatments in which seedlings had to compete with any weed competition had their growth compromised. Complete control of Urochloa was the best treatment for teak growth.
\end{abstract}

Keywords: Tectona grandis L.f., Urochloa decumbens Stapf, weeds, forest. 


\section{INTRODUCTION}

Teak (Tectona grandis L.f.) is a forest species belonging to the family Verbenaceae, native from the humid zones of the Indian sub-continent and Southeast Asia (ABRAF, 2013). This species is an alternative for the sustainable supply of forestry-based industries in Brazil (Rossi et al., 2011). Teak represented a little over $1 \%$ of the forest plantations in Brazil, in 2014, with approximately 87,499 ha, which represented an increase of $33.7 \%$ in comparison to the planted area in 2010 (IBÁ, 2015).

The importance and value of teak are due to the physical-mechanical properties of the wood, which are: durability, stability and ease of pre-treatment. Additionally, wood pattern, color and density are important qualitative aspects, making teak the most valuable broadleaf wood in the world (Vieira et al., 2002).

Similar to other forest species, teak must be planted and effectively managed from the early development stages. Initial management is essential, since it is the moment in which the plant presents a shallow and delicate root system, together with a little developed shoot that is susceptible to pests and diseases. Thus, the lack of care of the plantation makes the seedlings unable to compete with weeds in the cultivation area.

Brazil has approximately 140 million hectares of degraded areas (Tatagiba, 2012), consisting mostly of grazing land. Surveys show that, at least, one half of the grazing areas are being or are already degraded (Dias-Filho, 2005). Therefore, cattle grazers are introducing forest species into grazing areas, promoting extensive and long term beneficial soil alterations (Alvarenga et al., 2010). Such trees provide greater income from the commercialization of wood (Balbino et al., 2011), as well as promoting a microclimate that promotes greater thermal comfort for the animals when used in silvopastoral or agrosilvopastoral systems (Garcia et al., 2011). Cultivation of homogeneous forests in degraded areas is another interesting option, since it promotes the commercial use of these areas and their recovery over time (Carvalho et al., 2001; Franke et al., 2001; Nicodemo et al., 2004).

However, seed banks and prior crops that are not eradicated with management practices become a serious source of competition for the natural resources (Ekeleme et al., 2003) with the forest species, drastically affecting the plantation rotation cycle, which is already naturally long. According to Fonseca et al. (2006), Brazil has about 180 million hectares of grazing land, and the genus Urochloa is planted in $85 \%$ of the area, while the species Urochloa decumbens Stapf is used in 55\% of this total, thus justifying the need to determine the performance of teak under competition with this grass.

The importance of weed management is due to several factors, especially when one considers that the transplanted seedling undergoes a stress process when it is removed from the container and planted in the soil where it will grow and develop. Therefore, the forest species is frequently subjected to conditions completely different from to those of seedling production. Given this, weeds have a competitive advantage over seedlings, which can have such significant effect that it can lead to seedling death (Domingos \& Coelho, 2014).

This competition is considered one of the greatest problems in forest plantations and should be avoided as much as possible in the early formation stages of the forest stand, prior to canopy closure (Pitelli \& Marchi, 1991). Competition for light is not as limiting as that for water or nutrients. After the tree crop completely covers the soil surface, weed competition for light ceases (Locatelly \& Doll, 1977). The ability of each plant to obtain water is affected by soil exploration by the root system, plant physiology, ability to extract water from soil, stomata regulation, osmotic adjustment, and root hydraulic conductivity, among other factors (Radosevich et al., 1997) and in the case studied here, there is a great advantage of grasses over teak due to the significant seed density of the grasses in such areas (Santos et al., 2003). The combination of water and nutrients that should be used for the development of the planted crop, stimulates the germination of grass seeds, present in the seed bank, which due to their greater ability to absorb nutrients and faster growth, suppress or hinder teak's development (Domingos \& Coelho, 2014).

Considering that low productivity grazing areas can be replaced by homogeneous teak plantations, or that inter-planting can be done with forage and forest species, this study evaluated the vegetative development of this important forest species in a Urochloa pasture, without its control, with complete weed control, or with weed control after 6 months of competition, or with $60-\mathrm{cm}$ diameter crown control around teak seedlings. 


\section{MATERIAL AND METHODS}

This study was conducted on the P.U. Farm, located in the county of Urutaí/GO, at an altitude of $660 \mathrm{~m}$ and coordinates $17^{\circ} 27^{\prime} \mathrm{S}$ and $48^{\circ} 16^{\prime} \mathrm{W}$, with Aw climate, according to Köppen's classification (Alvares et al., 2013). The results of chemical and physical soil analysis $(0-20 \mathrm{~cm})$, at planting, were: $\mathrm{Ca}^{2+} 0.3 \mathrm{cmol}_{c} \mathrm{dm}^{-3}, \mathrm{Mg}^{2+} 0.8 \mathrm{cmol} \mathrm{dm}_{c}^{-3}, \mathrm{Al}^{3+} 0.0 \mathrm{cmol} \mathrm{dm}_{c}^{-3}$, $\mathrm{H}+\mathrm{Al} 2.7 \mathrm{cmol}_{\mathrm{c}} \mathrm{dm}^{-3}, \mathrm{~T} 4.24 \mathrm{cmol}_{\mathrm{c}} \mathrm{dm}^{-3}$, P-Meh $2.4 \mathrm{mg} \mathrm{dm}^{-3}$, $\mathrm{K}^{+} 168.0 \mathrm{mg} \mathrm{dm}^{-3}$, O.M. $21.0 \mathrm{~g} \mathrm{dm}^{-3}$, $\mathrm{pH}$ in $\mathrm{CaCl}_{2}$ 5.0, clay $340 \mathrm{~g} \mathrm{~kg}^{-1}$, silt $90 \mathrm{~g} \mathrm{~kg}^{-1}$, sand $570 \mathrm{~g} \mathrm{~kg}^{-1}$. Despite the soil analysis results, planting was performed according to the management strategies adopted by the farmers in the region, without soil acidity correction by liming, and applying fertilization of $150 \mathrm{~g}$ of formulated 05-25-15 per plant, applied below the seedling at the time of transplanting.

The experimental design was randomized blocks, consisting of four treatments and four replications. Each experimental unit consisted of five rows spaced at three meters, and nine plants per row, spaced two meters apart. Only the five central plants in the middle row were used for measurements, considering the other rows to be borders, as well as two plants at each end of the row.

The experiment demanded no phytosanitary treatments since it was isolated from other plantations and had no incidence of fungal diseases nor pests, except for the control of leaf cutting ants, which was performed by the personnel of the farm.

The experiment was installed in a well-formed pasture area, planted with Urochloa decumbens, with no invasive species, in May 2012. Teak seedlings used in the experiment were formed in the nursery on the farm. Teak fruits were harvested from the best and oldest teak stand on the farm, placed in jute sacks, submerged in running water of a creek for 24 hours and then sown in a sand bed. Seedlings containing two true leaves were transplanted from the sand bed to 2-L polyethylene bags containing soil and, sixty days later were ready for transplanting into the field.

The soil was plowed to open $40-\mathrm{cm}$ deep furrows and, subsequently, $15-\mathrm{cm}$ wide planting holes were dug, to transplant the seedlings. Seedlings were watered daily with approximately one liter per plant, for two months after transplanting into the field to ensure seedling survival.

Six months after transplanting, at the end of October, the area was subjected to the proposed treatments, which coincided with the rainy season and higher temperatures, resulting in favorable conditions for germination and development of Urochloa grass. Treatments consisted of no control of grass (T1), constant control of grass (T2), grass control after six months of competition, (T3), and control of grass in a $60-\mathrm{cm}$ crown around the seedling (T4). Treatments T1, T2 and T3 were maintained in the whole experimental unit, while for $\mathrm{T} 4$, the crowns were made individually in each plant. All treatments were maintained until final data collection in March 2014. Treatments $\mathrm{T} 2$ and $\mathrm{T} 33$ were maintained with the herbicide $\mathrm{GOAL}^{*} \mathrm{BR}$, active ingredient Oxifluorfem (4.0 $\mathrm{L} \mathrm{ha}^{-1}$ or $960 \mathrm{~g}$ a.i. ha ${ }^{-1}$ ), every other month, with the use of 20-L backpack sprayer, with a 110-02 fan spraying nozzle, adjusted for a volume of $200 \mathrm{~L} \mathrm{ha}^{-1}$. Treatment T4 was maintained weekly by hoeing the crowns.

Diameter at breast height (DBH) and total height of the five central trees of each plot were measured twenty two months after transplanting. Diameter was determined with a digital caliper, and height was measured using a graduated $8-\mathrm{m}$ pole.

Cylindrical volume was corrected by a form factor (f) to estimate the real volume of each tree and, thereby the stand volume. According to Drescher et al. (2010), the form factor that most closely matches the conditions found in this experiment was 0.64 .

Data was initially submitted to Levene's test, to determine the homogeneity of variances, which was accepted. Also, Kolmogorov-Smirnov's test confirmed that the distribution of the residues was normal. Subsequently, the data was submitted to analysis of variance, according to the model of randomized blocks and the averages compared by Tukey's test at 0.05 significance. All the analyses were done with ASSISTAT version 7.7 beta (Silva \& Azevedo, 2002). An estimative of the gain of each treatment in relation to the treatment under continuous competition was done.

\section{RESULTS AND DISCUSSION}

Since this forest species is cultivated almost exclusively for the timber industry, the parameters evaluated must show the effect the proposed treatments have on the 
quality of the product sent for processing. Height and diameter are fundamental to obtain long, wide blocks and boards, which are the most valuable on the market. Similarly, wood volume is of great importance in terms of final remuneration for the forest owner.

The experiment conducted in Urutaí, clearly shows the effect of Urochloa decumbens competition on initial teak development, with plant height being one of the main factors to be analyzed (Table 1). It was found that the only treatment significantly different from the others was the complete control of weed competition (T2). No significant differences were observed between any other weed control treatments, nor in relation to the control, which had no weed control.

Silva et al. (2012) evaluated eucalypt development under different weed control bands in two locations. The main weed in Araraquara was Panicum maximum Jacq, while Rhynchelytrum repens Willd. was predominant in Altinópolis and, for both areas, a minimum band of $75 \mathrm{~cm}$ width was required to minimize weed interference in eucalypt development. This demonstrates the great effect of weeds on crop development. By contrast, in this study, maintaining a $60-\mathrm{cm}$ diameter crown around teak (T3) and the treatment with no weed control for six months (T4) showed no significant difference from the treatment with no weed control (T1), demonstrating the need to widen the control band or to completely control weed competition by Urochloa with teak.

Another important parameter is the diameter at breast height since, together with plant height, it determines wood volume. Similarly to what was observed for plant height, diameter presented significant differences for one treatment in relation to the others, at $5 \%$ probability (Table 2 ), with only the treatment with no weed competition being favorable for teak development.

Tarouco et al. (2009), studying the effect of weeds on eucalypt plantations found that weed competition causes a reduction in stem diameter, similarly to what was observed in teak. Those authors found that weed control measures, during the first year after transplanting eucalypt seedlings into the field, should be adopted at the end of the period prior to interference, which occurred 107 days after seedling transplanting.

The comparison of the volume data highlighted even more, the gain of the weed control treatments in relation to the control (Table 3). These values are of fundamental importance, since forest farmers are paid directly for the wood volume produced by the stand.

Volume values maintained the same variation observed in the previous data, since continuous weed control resulted in greater volume than all other treatments, which showed no difference between each another. Greater tree growth tends to continue throughout the whole production cycle, favoring greater wood production in relation to trees subjected to any competition intensity with Urochloa.

Table 1. Height of teak subjected to four levels of Urochloa decumbens competition. Urutaí, GO, 2014.

\begin{tabular}{lcc}
\multicolumn{1}{c}{ Treatment } & $\begin{array}{c}\text { Height } \\
(\mathbf{m})\end{array}$ & $\begin{array}{c}\text { Gain } \\
(\mathbf{\%})\end{array}$ \\
\hline T1 - No control & $3.37 \mathrm{~b}$ & - \\
T2 - Total control & $5.47 \mathrm{a}$ & 62.31 \\
\hline T3 - Crown (60 cm diameter) & $4.00 \mathrm{~b}$ & 18.69 \\
\hline T4 - No control for the first 6 months & $4.08 \mathrm{~b}$ & 21.07 \\
CV (\%) & 11.38 & \\
msd & 1.0635 & \\
\hline
\end{tabular}

Averages followed by the same letter do not differ by Tukey's test at $5 \%$ probability.

Table 2. Diameter at breast height $(\mathrm{DBH})$ of teak subjected to four levels of Urochloa decumbens competition. Urutaí, GO, 2014.

\begin{tabular}{lcc} 
Treatment & $\begin{array}{c}\text { DBH } \\
(\mathbf{c m})\end{array}$ & $\begin{array}{c}\text { Gain } \\
(\%)\end{array}$ \\
\hline T1 - No control & $4.47 \mathrm{~b}$ & - \\
\hline T2 - Total control & $8.10 \mathrm{a}$ & 81.21 \\
\hline T3 - Crown (60 cm diameter) & $5.31 \mathrm{~b}$ & 18.79 \\
\hline T4 - No control for the first 6 months & $5.44 \mathrm{~b}$ & 21.70 \\
\hline CV $(\%)$ & 12.49 & \\
\hline msd & 1.6088 & \\
\hline
\end{tabular}

Averages followed by the same letter do not differ by Tukey's test at $5 \%$ probability.

Table 3. Plant volume $\left(\mathrm{V}_{\mathrm{p}}\right)$ and volume ha-1 $\left(\mathrm{V}_{\mathrm{ha}}\right)$ of teak subjected to four levels of Urochloa decumbens competition. Urutaí, GO, 2014.

\begin{tabular}{lccc}
\multicolumn{1}{c}{ Treatment } & $\begin{array}{c}\mathbf{V}_{\mathbf{p}} \\
\left(\mathbf{m}^{3}\right)\end{array}$ & $\mathbf{V}_{\text {ha }}$ & $\begin{array}{c}\text { Gain } \\
(\%)\end{array}$ \\
\hline T1 - No control & $0.00361 \mathrm{~b}$ & $6.02237 \mathrm{~b}$ & - \\
\hline T2 - Total control & $0.01816 \mathrm{a}$ & $30.24762 \mathrm{a}$ & 402.27 \\
\hline $\begin{array}{l}\text { T3 - Crown } \\
\text { (60 cm diameter) }\end{array}$ & $0.00605 \mathrm{~b}$ & $10.07552 \mathrm{~b}$ & 67.46 \\
$\begin{array}{l}\text { T4 - No control for } \\
\text { the first 6 months }\end{array}$ & $0.00629 \mathrm{~b}$ & $10.48154 \mathrm{~b}$ & 74.04 \\
\hline CV (\%) & 29.08 & & \\
\hline
\end{tabular}

Averages followed by the same letter do not differ by Tukey's test at $5 \%$ probability; $\mathrm{msd}\left(\mathrm{V}_{\mathrm{p}}\right)=0.00548 ; \mathrm{msd}\left(\mathrm{V}_{\mathrm{ha}}\right)=9.13104$. 
It is interesting to note that treatments T3 (60-cm crown) and T4 (no control for 6 months) had similar volumes. Thus, it can be stated that weed control within a 60-cm diameter crown has almost no effect on reducing weed competition. Additionally, allowing the co-existence of weed competition for the first six months of transplanting is enough to significantly reduce teak growth, demonstrating that the period prior to interference is less than 180 days, as determined by Tarouco et al. (2009) for eucalypt plantations.

Although the trees under constant competition (T1) presented the smallest values for all variables, the difference was marginal and non-significant in relation to the treatments with some degree of weed control (T3 and T4). Therefore, it is worth noting how important the first six months are for the establishment of teak plantations in areas that were previously pasture land. Moreover, maintaining weed control to a $60-\mathrm{cm}$ diameter crown is ineffective, since both treatments (T3 and T4) were similar to the constant presence of Urochloa grass in the area.

Data on percentage gain, as show in each table, demonstrates that greater gain was observed in diameter at breast height than in tree height for treatment T2 (constant control of weeds), highlighting that diameter is more affected by competition than height is. However, such a difference is even more expressive when data on diameter and height are combined into the volume, since the percentage gain increases by $67.46 \%$ in $\mathrm{T} 3$, $74.04 \%$ in $\mathrm{T} 4$ and by an impressive $402.27 \%$ in $\mathrm{T} 2$.

The evident sensitivity of teak to competition shows the importance of weed management for the success of forest stands, not only in relation to the duration of stand development until harvesting time, but also in relation to the production of trees with the properties that are desired by the timber industry, as observed by Coneglian (2014).

\section{CONCLUSIONS}

The best weed management strategy to obtain the greatest vegetative development in teak is complete elimination of weeds, while partial control, such as crowning around each plant was insufficient.

Teak plants grown under competition with Urochloa show reduced vegetative development, both in diameter and height. Such a reduction in diameter and height causes an even more significant reduction in tree volume.

\section{SUBMISSION STATUS}

Received: 24 mar., 2017

Accepted: 5 oct., 2017

\section{CORRESPONDENCE TO}

\section{Fausto Antônio Domingos Júnior}

Instituto Federal de Educação Ciência e

Tecnologia do Triângulo Mineiro - IFTM, Campus Uberaba, Rua João Batista Ribeiro, 4000, CEP 38064-790, Uberaba, MG, Brasil e-mail: fausto@iftm.edu.br

\section{REFERENCES}

Alvarenga RC, Porfírio-da-Silva V, Gontijo Neto MM No, Viana MCM, Vilela L. Sistema Integração Lavourapecuária-floresta: condicionamento do solo e intensificação da produção de lavouras. Belo Horizonte: Embrapa Milho e Sorgo; 2010.

Alvares CA, Stape JL, Sentelhas PC, Gonçalves JLM, Sparovek G. Köppen's climate classification map for Brazil. Meteorologische Zeitschrift 2013; 22(6): 711-728. http:// dx.doi.org/10.1127/0941-2948/2013/0507.

Associação Brasileira de Produtores de Florestas Plantadas - ABRAF. Anuário Estatístico 2013. Brasília: ABRAF; 2013.

Balbino LC, Cordeiro LAM, Martínez GB. Contribuições dos Sistemas de Integração Lavoura-pecuária-floresta (iLPF) para uma Agricultura de Baixa Emissão de Carbono. Revista Brasileira de Geografia Física 2011; 4(6): 1163-1175. http://dx.doi.org/10.26848/rbgf.v4i6.232775.

Carvalho MM, Xavier DF, Alvim MJ. Características de algumas leguminosas arbóreas adequadas para a associação com pastagens. Juiz de Fora: Embrapa Gado de Leite; 2001.

Coneglian A. Tecnologia da madeira de teca (Tectona grandis). In: Coelho L, Nascimento ART, Lemes EM, editores. Espécies nobres no cerrado. I - Silvicultura e perspectivas de produção. Uberlândia: Composer; 2014.

Dias-Filho MB. Degradação de pastagens: processos, causas e estratégias de recuperação. 2rd ed. Belém: Embrapa Amazônia Oriental; 2005.

Domingos FA Jr, Coelho L. Controle de plantas infestantes em plantios florestais. In: Coelho L, Nascimento ART, Lemes EM, editores. Espécies nobres no cerrado. I - Silvicultura e perspectivas de produção. Uberlândia: Composer; 2014. 
Drescher R, Pelissari AL, Gava FH. Fator de forma artificial para povoamentos jovens de Tectona grandis em Mato Grosso. Pesquisa Florestal Brasileira 2010; 30(63): 191-197. http://dx.doi.org/10.4336/2010.pfb.30.63.191.

Ekeleme F, Akobundu IO, Isichei AO, Chikoye D. Cover crops reduce weed seedbanks in maize-cassava systems in Southwestern Nigeria. Weed Science 2003; 51(1): 774-780. http://dx.doi.org/10.1614/0043-1745(2003)051[0774:CC RWSI]2.0.CO;2.

Fonseca DM, Martuscello JA, Faria DJG. Adubação em gramíneas do gênero Brachiaria: mitos e realidades. In: Anais do III simpósio sobre manejo estratégico das pastagens; 2006; Viçosa. Viçosa: Universidade Federal de Viçosa; 2006. p. 153-182.

Franke IL, Lunz AMP, Valentim JF, Amaral EF, Miranda EM. Situação atual e potencial dos sistemas silvipastoris no Estado do Acre. In: Carvalho MM, Alvim MJ, Carneiro JC, editores. Sistemas agroflorestais pecuários: opções de sustentabilidade para áreas tropicais e subtropicais. Juiz de Fora: Embrapa Gado de Leite; 2001.

Garcia RG, Matos LB, Lourenço Júnior JB, Nahúm BS, Araújo CV, Santos AX. Variáveis fisiológicas de búfalas leiteiras criadas sob sombreamento em sistemas silvipastoris. Pesquisa Agropecuária Brasileira 2011; 46(10): 1409-1414. http://dx.doi.org/10.1590/S0100-204X2011001000039.

Indústria Brasileira de Árvores - IBÁ. Relatório Ibá 2015. São Paulo: Pöyry Consultoria em Gestão e Negócios Ltda; 2015.

Locatelly E, Doll JD. Competencia y alelopatis. In: DOLL JD, editor. Manejo y control de malezas en el trópico. Cali: CIAT; 1977.

Nicodemo MLF, Porfírio-Da-Silva VP, Thiago LRLS, Gontijo Neto MM, Laura V. Sistemas Silvipastoris: introdução de árvores na pecuária do Centro-Oeste brasileiro. Campo Grande: Embrapa Gado de Corte; 2004.

Pitelli RA, Marchi SR. Interferência das plantas invasoras nas áreas de reflorestamento. In: Anais do III Seminário
Técnico Sobre Plantas Daninhas e o Uso de Herbicidas em Reflorestamento; 1991; Belo Horizonte. Belo Horizonte: SIF; 1991. p. 110-123.

Radosevich S, Holt J, Ghersa C. Weed ecology: implications for management. 2rd ed. New York: Willey; 1997.

Rossi AS, Drescher R, Pelissari AL, Lanssanova LR. Relação hipsométrica e crescimento de Tectona grandis L.f. no município de Monte Dourado, Pará. Scientia Forestalis 2011; 39(91): 301-307.

Santos JB, Procópio SO, Silva AA, Costa LC. Captação e aproveitamento da radiação solar pelas culturas da soja e do feijão e por plantas daninhas. Bragantia 2003; 62(1): 147 153. http://dx.doi.org/10.1590/S0006-87052003000100018.

Silva FASE, Azevedo CAV. Versão do programa computacional Assistat para o sistema operacional Windows. Revista Brasileira de Produtos Agroindustriais 2002; 4(1): 71-78. http://dx.doi.org/10.15871/1517-8595/rbpa.v4n1p71-78.

Silva JRV, Alves PLC, Toledo REB. Weed control strip influences the initial growth of Eucalyptus grandis. Acta Scientiarum. Agronomy 2012; 34(1): 29-35. http://dx.doi. org/10.4025/actasciagron.v34i1.12252.

Tarouco CP, Agostinetto D, Panozzo LE, Santos LS, Vignolo GK, Ramos LOO. Períodos de interferência de plantas daninhas na fase inicial de crescimento do eucalipto. Pesquisa Agropecuária Brasileira 2009; 44(9): 1131-1137. http://dx.doi.org/10.1590/S0100-204X2009000900010.

Tatagiba F. Áreas degradadas do Brasil equivalem a duas Franças, diz Ministério do Meio Ambiente [online]. Brasília: Correio do Brasil; 2012 [cited 2012 jul. 12]. Available from: http://www.correiodobrasil.com.br/ areas-degradadas-do-brasil-equivalem-a-duas-francasdiz-ministerio-do-meio-ambiente/485166

Vieira AH, Martins EP, Pequeno PLL, Locatelli M. Aspectos silviculturais da teca em Rondônia. Porto Velho: Embrapa CPAF - Ministério da Agricultura, Pecuária e Abastecimento; 2002. 